University of Chicago Law School

Chicago Unbound

Public Law and Legal Theory Working Papers

Working Papers

2009

\title{
A Minimalist Charter of Rights for Australia: The U.K. or Canada as a Model?
}

Rosalind Dixon

Follow this and additional works at: https://chicagounbound.uchicago.edu/public_law_and_legal_theory

Part of the Law Commons

Chicago Unbound includes both works in progress and final versions of articles. Please be aware that a more recent version of this article may be available on Chicago Unbound, SSRN or elsewhere.

\section{Recommended Citation}

Rosalind Dixon, "A Minimalist Charter of Rights for Australia: The U.K. or Canada as a Model?" (University of Chicago Public Law \& Legal Theory Working Paper No. 285, 2009).

This Working Paper is brought to you for free and open access by the Working Papers at Chicago Unbound. It has been accepted for inclusion in Public Law and Legal Theory Working Papers by an authorized administrator of Chicago Unbound. For more information, please contact unbound@law.uchicago.edu. 


\title{
CHICAGO
}

Public LaW ANd Legal Theory Working Paper No. 285

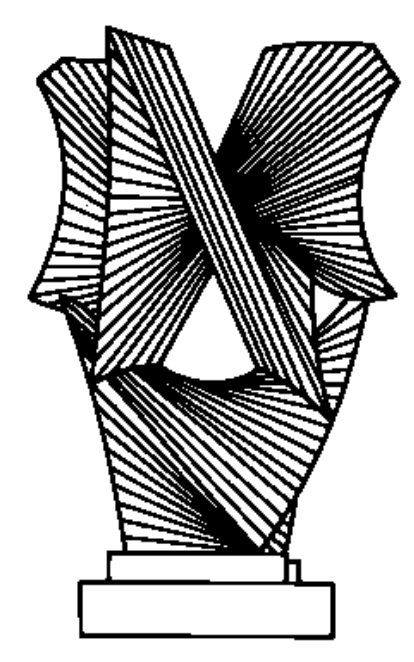

\section{A MinimaList CHARTER OF RigHTS FOR AUSTRALIA: THE U.K. OR CANADA AS A MODEL?}

\author{
Rosalind Dixon
}

\section{THE LAW SCHOOL THE UNIVERSITY OF CHICAGO}

November 2009

This paper can be downloaded without charge at the Public Law and Legal Theory Working Paper Series: http://www.law.uchicago.edu/academics/publiclaw/index.html and The Social Science Research Network Electronic Paper Collection. 


\title{
A MINIMALIST CHARTER OF RIGHTS FOR AUSTRALIA: THE U.K. OR CANADA AS A MODEL?
}

\author{
Rosalind Dixon*
}

Minimalist: Involving minimum change or intervention

- Oxford English Dictionary

Most commentators agree that, if Australia is to adopt a charter of rights, such a charter should so far as possible involve a 'minimalist' form of constitutional change. ${ }^{1}$ It should both be enacted by ordinary statute and seek to preserve broad scope for the Commonwealth Parliament, in appropriate cases, to override the interpretation of non-constitutional rights by the High Court. When it comes to questions of form and enforceability, the thinking is that it should be modelled on either the Human Rights Act 1998 (UK) c 42 ('UK $H R A$ '), and the largely equivalent state statutory charters in the ACT and Victoria, ${ }^{2}$ or on the Canadian Bill of Rights, SC 1960, c 44 ('CBOR').

Not only would a statutory charter of this kind be easier to adopt than a more entrenched model of charter, such as a charter modelled on the US Bill of Rights, the Canadian Charter of Rights and Freedoms 1982 (the second and later of Canada's two operative human rights charters) ('Canadian Charter'), or Constitution of the Republic of South Africa 1996. By formally preserving broad scope for Parliament to

* Assistant Professor of Law, University of Chicago Law School. The author wishes to thank Peter Cane, Harry Dixon, Marion Dixon, Carolyn Evans, Richard Holden, Andrew Lynch, Ed Santow, Cheryl Saunders and Adrienne Stone for helpful comments and suggestions on earlier drafts of this article, and the issues raised by it. Thanks are also due to Jennifer Dougherty and Emily Tancer for excellent research assistance.

1 For the idea of minimalism in constitutional law, particularly as applied to the process of judicial review, see Cass R Sunstein, One Case At A Time: Judicial Minimalism on the Supreme Court (1999).

2 See Human Rights Act 2004 (ACT) ('ACT HRA'); Victorian Charter of Rights and Responsibilities 2006 (Vic) ('Victorian Charter'). For relevant differences, see, eg, Carolyn Evans, 'British Influences on Australian Human Rights Acts' (Paper presented at the Faculty of Law, Oxford University, 24 April 2007); Simon Evans, 'The Victorian Charter of Rights and Responsibilities and the ACT Human Rights Act: Four Key Differences and their Implications for Victoria,' Paper presented at the Australian Bills of Rights: The ACT and Beyond Conference, Canberra, 21 June 2006. In many ways, the Bill of Rights 1990 (NZ) is also another model in this same broad category, but as a potential precedent raises certain additional complications. One complication is that it contains no express power to make a declaration of incompatibility or inconsistency, and therefore to the extent such a power is judged desirable even on minimalist grounds, raises unnecessary complications. Another difficulty is that it has been interpreted by the New Zealand Court of Appeal. To imply certain fairly maximalist remedies, including a right to damages for the breach of the Act: see, eg, Simpson v A-G [1994] 3 NZLR 667 ('Baigent's Case'). For some, this raises concerns about the stability of weak-form judicial review: see, eg, James Allan, 'Take Heed Australia — A Statutory Bill of Rights and Its Inflationary Effect'(2001) 6 Deakin Law Review 322, 333 (discussing the emotive power of 'rights talk' referencing a bill of rights); Grant Huscroft, 'Protecting Rights and Parliamentary Sovereignty: New Zealand's Experience with a Charter Inspired, Statutory Bill of Rights' (2002) 21 Windsor Yearbook of Access to Justice 111, 129 (arguing that increased rights-consciousness produces a strong gravitational pull away from weak-form judicial review); Mark Tushnet, 'Judicial Activism or Restraint in a Section 33 World' (2003) 53 University of Toronto Law Journal 89, 89-90. However, it may also reflect more specific problems associated with the design of the NZBOR, and the approach of some members of the New Zealand Court of Appeal in the early years of the operation of the NZBOR: see, eg, Andrew S Butler, 'Declaration of Incompatibility or Interpretation Consistent with Human Rights in New Zealand' (2001) Public Law 28 (on design); Anna Adams, 'Competing Conceptions of the Constitution: The New Zealand Bill of Rights Act 1990 and the Cooke Court of Appeal' (1996) New Zealand Law Review 368 (summarizing the approach of Lord Cooke and other members of the Cooke court to the NZBOR). 
override a decision of the High Court in respect of rights, it would also, proponents argue, be more respectful of existing democratic commitments than a US-style rights charter. ${ }^{3}$

As between the two different statutory charter models provided by the UK HRA and CBOR, when it comes to the question of judicial enforcement, most charter commentators further suggest that the British model is the more minimalist of the two. ${ }^{4}$ By purporting to limit the power of courts to declare legislation invalid for inconsistency with a rights charter, or adopting a system of 'weak remedies, ${ }^{15}$ the British model not only gives Parliament formal power to amend or expressly to suspend rights as they have been interpreted by the Court, but also the formal power to decline to respond to a declaration of incompatibility by the Court. It is therefore even closer, so the argument goes, to Australia's current system of human rights protection. ${ }^{6}$ Partly for this reason, it is also now the model endorsed by National Human Rights Consultation Committee in its Final Consultation Report. ${ }^{7}$

While sympathetic to the idea of charter minimalism, this paper challenges this minimalist orthodoxy favouring a British-style charter.

At the level of substance, rather than form, charter minimalism requires not only that Parliament retain the ultimate power to override decisions of the High Court in respect of rights, but also that Parliament be in practice willing to contribute to defining the scope and priority to be given to particular rights. If the Court insists that, in order to achieve this, Parliament must rely exclusively on a formal power of override, then the process is likely to fail. For members of Parliament, the political costs of engaging in dialogue will simply be too high in most cases. A truly minimalist charter, if indeed it is achievable, therefore requires that under such a charter the Court be willing to empower members of Parliament to engage in dialogue via more ordinary legislative means. ${ }^{8}$ For the Court, this means avoiding an unduly strained approach to the interpretation of statutory language and intention, and, in some 'second look' cases, even showing additional deference to the constitutional judgments of Parliament. ${ }^{9}$

A British-style charter directly undermines the likelihood that the Court will adopt such an approach to the interpretation of statutes, at least in cases that purport to determine individual rights and liabilities once and for all. In such civil and criminal, or non-pure public law, cases, judges under a UK-style charter

3 It should, of course, be noted that the degree to which the US leaves scope for democratic dialogue between the Supreme Court and the elected branches, either via United States Constitution art V, § 5 of the Fourteenth Amendment or otherwise, is itself a contested question.

4 When it comes to the substantive rights the two charters protect, the $C B O R$ is generally agreed to be much narrower and to that extent more minimalist - but potentially too much so. See Walter S Tarnopolsky, 'The Historical and Constitutional Context of the Proposed Canadian Charter of Rights and Freedoms' (1981) 44(3) Law and Contemporary Problems 169. See also Part III below.

5 On the distinction between strong - versus weak-forms of review, see Mark Tushnet, Weak Courts, Strong Rights: Judicial Review and Social Welfare Rights in Comparative Constitutional Law (2008).

6 See, eg, Hilary Charlesworth, 'Who Wins under a Bill of Rights?' (2006) 25 University of Queensland Law Journal 39, 50 (arguing that, whatever the merits of democratic concerns about judicial review in the name of human rights, such concerns are directly answered by such a power); Geoffery Robertson, The Statute of Liberty: How Australians Can Take Back their Rights (2009) 47-48 (arguing for such a model as representing a true 'half-way' house model); George Williams, 'The Victorian Charter of Human Rights and Responsibilities: Origins and Scope' (2006) 30 Melbourne University Law Review 880.

7 See National Human Rights Consultation Committee, Final Report: Recommendations (2009).

8 The concept of dialogue is itself a potentially contested one which merits careful treatment. See Rosalind Dixon, Designing Constitutional Dialogue: Bills of Rights \& The New Commonwealth Constitutionalism (SJD Thesis, Harvard University, 2008); Leighton McDonald, 'Rights, "Dialogue" and Democratic Objections to Judicial Review' (2004) 32 Federal Law Review 1, 26-28; Tom Campbell, 'Does Anyone Win Under a Bill of Rights? A Response to Hilary Charlesworth's "Who Wins under a Bill of Rights?"' (2006) 25 University of Queensland Law Journal 55, 59; Joo-Cheong Tham and Kenneth D Ewing, 'Limitations of a Charter of Rights in the Age of Counter-Terrorism' (2007) 31 Melbourne University Law Review 462, 270-3; Rosalind Dixon, 'The Supreme Court of Canada, Charter Dialogue \& Deference' 47 Osgoode Hall Law Journal (Forthcoming, 2009). For scepticism about the possibility of such dialogue, see, eg, Allan, above n 2; Grant Huscroft, 'Rationalizing Judicial Power: The Mischief of Dialogue Theory' in James B Kelly and Christopher P Manfredi (eds), Contested Constitutionalism: Reflections on the Charter of Rights and Freedoms (2009); Andrew Petter, 'Taking Dialogue Theory Much Too Seriously (or Perhaps Charter Dialogue Isn't Such a Good Thing After All)' (2007) 45 Osgoode Hall Law Journal 147.

9 On the concept of second look cases, see Peter W Hogg and Allison A Bushell, 'The Charter Dialogue between Courts and Legislatures (Or Perhaps the Charter of Rights Isn't Such a Bad Thing After All)' (1997) 35 Osgoode Hall Law Journal 75. 
face an extremely hard remedial choice, between, on the one hand, ensuring justice to individuals as they see it, and on the other, respecting the bounds of their limited remedial authority. Given their common law training and sensibility, when faced with this choice, judges will often choose to prioritize the interests of individuals at the expense of giving meaningful effect to the language and intent of a statute, a process resulting in broad statutory distortion. By this means, judges will also tend to undermine the capacity of Parliament to engage effectively in ordinary dialogue with the Court.

In Australia this danger of statutory distortion will be even more acute, given the doubts surrounding the constitutionality of the High Court's issuing, or hearing appeals against the grant of, certain weakform remedies. While Ch III of the Australian Constitution (the 'Constitution') need not ultimately create any serious obstacle to the adoption of a British-style rights charter in Australia, ${ }^{10}$ there is clearly room for reasonable disagreement, and therefore uncertainty, on this question. By itself, uncertainty of this kind also has a clear potential, in the crucial early years of a charter's operation, to distort the approach of lower courts to the grant of weak remedies.

By contrast, whether modelled on either the CBOR or the later more entrenched Canadian Charter, a Canadian-style rights model of strong judicial remedies is both more likely in the first place to deliver the 'true value' of statutes and also to be unaffected by the difficulties and doubts created by Ch III of the Constitution. Accordingly, it is also substantially less likely than a UK-style rights charter to lead to a form of de facto strong rather than weak or dialogic judicial review. ${ }^{11}$ Translated into a contemporary Australian context, a Canadian-style charter is also unlikely, even in a pure statutory form, to create anything like the same problem of overly weak, as opposed to overly strong, judicial review associated with the CBOR itself. $^{12}$

The more realistic danger is that even a Canadian-style statutory rights charter is likely to be interpreted by the Court in a way that is insufficiently, rather than too, deferential; and in this context, Canadian experience, under the more entrenched Canadian Charter of Rights and Freedoms 1982, again offers a useful model for Australia. The challenge for the drafters of any Australian rights charter will be to encourage both the High Court to emulate this model; and Parliament to follow the lead of Canadian legislators in enacting the kind of legislative sequels necessary for such a model to succeed. In the latter context in particular, comparative experience further suggests the chances of success will tend to be lower, rather than higher, under a British-style charter, with its attendant dangers of statutory distortion, than under either a statutory or entrenched Canadian-style charter.

On purely minimalist criteria, the paper argues, a Canadian-style rights charter modeled on the CBOR therefore clearly dominates a British-style charter. If a British-style charter is to be defended as a preferred charter model, it accordingly cannot be on minimalist grounds alone.

The paper is divided into four parts. Part I sets out in more detail the contours of the British and Canadian-style statutory rights models, and explains how, by preserving a power of Parliamentary override, both models could help maintain the current legislative-judicial balance between the High Court and Parliament. Part II discusses the even greater importance, from the point of view of judiciallegislative balance, of the High Court interpreting legislation in a way which is relatively stable and 'true' to Parliament's choice of language; and the degree to which a British-style charter is more prone to interpretive distortion both generally, and in Australia in particular. Part III considers the ability of a Canadian-style rights charter, modelled on the $C B O R$, to avoid the extremes of both strong- and weakform judicial review. Part IV concludes by discussing other potential criteria, aside from the substance of the rights they protect, on which a British- and Canadian-style charter might be assessed.

\section{THE TWO STATUTORY MODELS AND EXTRAORDINARY LEGISLATIVE DIALOGUE}

Compared to most other constitutional democracies, Australia currently has a human rights system which is strongly Parliament-centred.

When interpreting statutes, or even in developing the common law, the High Court will often seek to advance a different view from that of Parliament about the protection due to particular common law or

10 See Gageler opinion.

11 For criticism of the UK HRA on these grounds, see, eg, Tom Campbell, 'Incorporation through Interpretation' in Adam Tomkins et al (eds), Skeptical Essays on Human Rights (2001) 85; Aileen Kavanagh, Constitutional Review under the UK Human Rights Act (2009).

12 Only one statute was actually invalidated by the SCC under the CBOR. See below n 114. 
international human rights. In order to do so the Court will, where necessary, read down statutory language so as to ensure that the statute conforms in its operation to the Court's view of the preferred scope or priority to be given to particular common law rights, such as the right to (informational) privacy, or the right to liberty and security of the person. ${ }^{13}$ It will also at times read down statutes to conform to international human rights standards. ${ }^{14}$ In a common law context, the Court has also indicated a willingness to use its power to develop the law so as to advance particular justices' conception of international human rights, such as the right to a fair trial, and the right to freedom from racial discrimination. ${ }^{15}$

However, in each case, if Parliament disagrees with the way in which the High Court chooses to interpret particular rights commitments, it has near unlimited freedom to pass legislation giving effect to a different interpretation of rights. In most cases, if Parliament uses clear language, it can by ordinary majority vote amend or impliedly repeal (i.e. suspend) the operation of particular rights, as they have been interpreted by the Court. The only exception relates to rights to political communication and basic political participation, to judicial review of unlawful government action, trial by jury, religious freedom and (arguably) property. ${ }^{16}$ Parliament is thus in practice at least equal, if not superior, to the Court in determining the scope and priority to be given to most individual rights. ${ }^{17}$

If a new rights charter is to maintain this balance between the Court and Parliament, it too must therefore give Parliament broad power to amend and/or suspend rights as they have been interpreted by the Court. Both a UK HRA and CBOR-style Charter also clearly meet this requirement.

In the UK, the substantive rights protected by the UK HRA are those rights guaranteed by various provisions of the Convention for the Protection of Human Rights and Fundamental Freedoms (the 'Convention'), as well those contained in the first and sixth protocols to the Convention, and which are also specifically incorporated as 'Convention rights' protected by the Act. ${ }^{18}$ Because the HRA has the formal status of an ordinary statute, the Westminster Parliament can, by ordinary majority vote, amend the substantive scope of the HRA by simply repealing, either in whole or in part, the incorporation of particular Convention rights. Subject to the constraints imposed by s 3 of the HRA, discussed further below, Parliament can also impliedly suspend the operation of particular Convention rights by careful choice of language. Section 14 of the HRA also expands this power of suspension by providing that the executive (i.e. the Secretary of State) retains power under the Act, not just the Convention, to suspend the operation of Convention rights for a five-year renewable period. ${ }^{19}$

In Canada too, the $C B O R$ was enacted as an ordinary act of the Canadian Parliament. Section 1 of the $C B O R$ recognizes and declares certain individual rights, including the right of individuals, without discrimination: (a) to life, liberty, security of the person and enjoyment of property, and the right not to be deprived thereof except by due process of law; (b) equality before the law and the protection of the law; (c) freedom of religion; (d) freedom of speech; (e) freedom of assembly and association; and (f) freedom of the press, so that even more than in the UK, the Canadian Parliament has clear power to vary the scope of protected rights by ordinary legislative amendment. Providing Parliament uses clear, express

13 See, eg, Potter v Minahan, (1908) 7 CLR 277, 304; Coco v The Queen (1994) 179 CLR 427; Al-Kateb v Godwin (2004) 219 CLR 562, 577 (Gleeson CJ) ('Al-Kateb').

14 See Polites v Commonwealth (1945) 70 CLR 60, 68-69, 77, 80-8 (regarding international law generally); Kartinyeri $v$ The Commonwealth (1998) 195 CLR 337, 384 (Gummow and Hayne JJ). This, though, is a more contested principle of statutory interpretation: see eg Al-Kateb (2004) 219 CLR 562, 662 (Heydon J). But see Al-Kateb (2004) 219 CLR 562, 590 (McHugh J) (arguing that the principle is firmly established).

15 See, eg, Dietrich v The Queen (1992) 177 CLR 292; Mabo v Queensland (No 2) (1992) 175 CLR 1 [126] (Brennan CJ).

16 See Lange v Australian Broadcasting Corporation (1997) 189 CLR 520 (freedom of political communication); Roach v Electoral Commissioner (2007) 233 CLR 162 (prohibition against arbitrary restrictions on the franchise, or basic political communication); Constitution ss 51(xxxi), 75(v), 80, 116. For discussion of the significance of s 75(v) in this context, see Pamela Tate, 'Protecting Human Rights in a Federation' (2007) 33 Monash University Law Review 220, 223-24; for debate about the significance of s 51(xxxi) as a true rights guarantee, see Rosalind Dixon, 'Overriding Guarantee of Just Terms or Supplementary Source of Power?: Rethinking s 51(xxxi) of the Constitution' (2005) 27 Sydney Law Review 639.

17 As a formal matter, the doctrine of parliamentary sovereignty means that Parliament is, of course, superior to the Court in this context: see generally Julie Taylor, 'Human Rights Protection in Australia: Interpretation Provisions and Parliamentary Supremacy' (2004) 32 Federal Law Review 57.

18 Human Rights Act 1998 (UK) c 42, s 2.

19 See Human Rights Act 1998 (UK) c 42, ss 14, 16. 
language, the SCC has also held that Parliament retains unlimited power to suspend the operation of the rights protected by s 1.20

For many commentators, however, compared to the CBOR, the UK HRA also offers a valuable additional mechanism for maintaining the existing balance in Australia between the Court and Parliament, by limiting the remedial powers open to courts. In Canada, the SCC has held that the CBOR authorizes the Court to make a declaration of inconsistency which deprives a subsequent statute of legal force and effect. Because s 2 of the CBOR provides that no law 'shall be construed or applied' (emphasis added) so as to 'abrogate, abridge or infringe' the rights protected by s 1, 'unless it is expressly declared by an Act of the Parliament of Canada that it shall operate notwithstanding the Canadian Bill of Rights', the SCC has held that, notwithstanding its status as an ordinary statute, the CBOR gives courts the power, traditionally associated with strong-form Constitutional-style review, to invalidate legislation for inconsistency with $\mathrm{s} 1 .^{21}$ (This, of course, is the power the High Court exercises when it finds incompatibility between the Constitution and a federal or state statute.) This means that, whatever interpretation of s 1 of the $C B O R$ courts adopt, that interpretation has automatic legal effect, even if Parliament disagrees with that interpretation.

Under a British-style charter, by contrast, any declaration of incompatibility by a court has no immediate legal effect. Instead, Parliament retains express legal power not to respond or implement a declaration of incompatibility with which it disagrees (a power of 'non-implementation'). Section 3 of the UK HRA provides that British courts have an obligation 'so far as it is possible to do so' to 'read and giv[e] effect' to legislation 'in a way which is compatible with the Convention rights'. ${ }^{22}$ Where such a reading is impossible, courts further provide that courts may make a 'declaration of incompatibility', ${ }^{23}$ but such a declaration 'does not affect the validity, continuing operation or enforcement of the provision in respect of which it is given; and is not binding on the parties to the proceedings in which it is made'. ${ }^{24}$ Parallel provisions, regarding the making of a declaration of incompatibility, are also found in s 32 of the ACT HRA and s 28 of the Victorian Charter, and by implication, under the Bill of Rights 1990 (NZ). ${ }^{25}$

Because of this, proponents of a British-style charter argue that such a charter gives legislatures three, rather than just two, potential methods by which it may override a court decision with which it disagrees - amendment, suspension and non-implementation. Proponents of a national human rights charter in Australia therefore also argue that, as between the two statutory models represented by the UK HRA and $C B O R$, a British-style charter is the more respectful of the current balance between the Court and Parliament - and to that degree, also more minimalist. ${ }^{26}$

\section{THE TWO STATUTORY MODELS AND ORDINARY LEGISLATIVE DIALOGUE}

\section{A The importance of ordinary dialogue}

A crucial factor to bear in mind in this context, however, is the way in which Parliament is most likely to engage in rights dialogue with the High Court under any new national rights charter.

As Jeremy Waldron has noted, there are two potential reasons why legislators may disagree with judges about the application of particular charter rights. One reason is that they believe that the rights in question have no proper application to a particular given context - i.e. they have 'misgivings' about the application of rights. ${ }^{27}$ Another is that they may disagree with judges about the exact content or priority to be given to the relevant rights in given context ('rights disagreements'). ${ }^{28}$ Both reasons for disagreement are potentially principled. The key difference between the two is simply in the breadth of disagreement involved.

A legislative power of amendment or suspension, however, will tend to be far better suited to expressing the first, rather than second, of these sources of disagreement.

\section{$R v$ Drybones [1970] SCR 282.}

Ibid.

Human Rights Act 1998 (UK) c 42, s 3.

Human Rights Act 1998 (UK) c 42, s 4.

Human Rights Act 1998 (UK) c 42, s 4(6).

Moonen v Film and Literature Board of Review [2000] 2 NZLR 9.

Tate, above n 15, 234.

Jeremy Waldron, 'Some Models of Dialogue Between Judges and Legislators' in Grant Huscroft and Ian Brodie (eds), Constitutionalism in the Charter Era (2004) 7.

Ibid. 
In order to override a court's interpretation of rights, via reliance on a power of amendment or suspension, Parliament will necessarily be required to use language which suggests that particular rights are inapplicable to - or not broad enough to cover - particular circumstances; and this inevitably constitutes a representation that Parliament has rights misgivings in a given context. In cases where this is not in fact the case, and Parliament is instead being required to misrepresent the nature and scope of its disagreement with a court, this misrepresentation can, in turn, have serious consequences for the costs to legislators of engaging in dialogue. ${ }^{29}$

When legislators decline to protect individual rights in a given setting, there is always the possibility that they are motivated by pure political expediency, rather than principled disagreement. This means that the public will rightfully be skeptical of legislation which purports to disregard human rights norms, unless it can be persuaded that such disregard for rights is either necessary or appropriate. Legislators will also find it much harder to meet this burden of persuasion when they have engaged in any form of misrepresentation - because in these circumstances, they will likely seem far less generally trustworthy to the public.

Given this, the safest way to engage in dialogue for legislators who have rights disagreements, rather than rights misgivings, in relation to a court decision will be, at least in the first instance, via ordinary legislation purporting to modify the effect of a court decision (ordinary dialogue). ${ }^{30}$

Unlike a statute which amends or suspends a rights charter, ordinary legislation of this kind does not purport to ignore the need to accommodate human rights in a particular context - and therefore attracts far less public skepticism and distrust. Because it is less likely to be interpreted by courts in a way which achieves purely expedient ends, it is also a credible signal by legislators that they are motivated by principled disagreement, rather than expediency, in seeking to narrow the effect of a prior court decision protecting individual rights. ${ }^{31}$

If it were to fail in a 'second look' judicial challenge, as a first attempt at dialogue, such ordinary legislation would also place a legislature in a much stronger position to persuade the public that it was justified in using more extreme measures in seeking to engage in dialogue with the Court - such as a power of amendment, suspension or non-implementation (extraordinary dialogue). Use of such measures would in that case be much less likely, than if used at an earlier stage, to be perceived by the public as the pure product of expediency, rather than principled disagreement.

This emphasis on ordinary tools for legislative dialogue means that if any additional power of extraordinary dialogue is to promote, rather than undermine, Parliament's interpretive authority under a rights charter, it must ensure that courts continue to respect the language and intention of statutes. ${ }^{32}$

The difficulty with a British-style rights charter, in this context, is that it creates very strong incentives for courts to disrespect, rather than respect, legislative language and intention - in the name of advancing the protection of individual rights.

The reason for this is that, if courts under a British-style charter rely on a declaration incompatibility, rather than power of reading down, individual plaintiffs may ultimately be denied all form of legal relief. Not only will plaintiffs be denied immediate legal relief from the court itself. Much more troubling, in many civil and criminal cases parliaments may, also have limited capacity to provide such relief. ${ }^{33}$

29 On the misrepresentation involved, see ibid 37.

30 For the contrary argument, that a formal power of legislative override should be understood to exhaust the scope for Parliamentary dialogue involving actual interpretive disagreement, see, eg, Peter Hogg, Alison Bushell Thornton and Wade Wright, 'Charter Dialogue Revisited — Or "Much Ado About Metaphors"' (2007) 45 Osgoode Hall Journal 47-8.

31 Cf Michael Spence, 'Job Market Signalling' (1973) 87 Quarterly Journal of Economics 355. The key to it being a credible signal in this context is that, given the degree to which courts generally defer far less to such legislation than amending or suspending legislation, it would almost always be more costly for expedient 'types' to rely on this path, rather than formal amendment or suspension, as a path for achieving expedient ends.

32 For similar arguments, though from somewhat different perspectives in relation to the interpretation of Australian state, UK and NZ rights charters, see, eg, James Allan, 'The Victorian Charter of Human Rights and Responsibilities: Exegisis and Criticism' (2006) 30 Melbourne University Law Review 906; Butler, above n 2, 35; Campbell above n 9, 87; C A Gearty, 'Reconciling Parliamentary Democracy and Human Rights' (2002) 118 Law Quarterly Review 248, 254; Paul Rishworth, 'Common Law Rights and Navigation Lights: Judicial Review and the New Zealand Bill of Rights' (2004) 15 Public Law Review 103, 116.

33 In this sense, I do not share the view of many commentators that judicial rather than legislative relief is an inherently necessary condition for the effective protection of individual rights. 
Consider a case such as Ghaidan $v$ Godin-Mendoza ('Ghaidan'), ${ }^{34}$ decided by the House of Lords under s 4 of the HRA. ${ }^{35}$ The issue in Ghaidan was whether a same-sex partner could obtain the same benefit, of a statutory tenancy, as that enjoyed by the 'spouse' of a deceased tenant. (Other family members were entitled to a lesser form of protected tenancy, according to which the landlord had the right to adjust the rent paid.) Relying on s 3 of the UK HRA, the Legal Committee of the House of Lords in Ghaidan held that the definition of spouse, as persons living 'as [the] wife or husband' should be interpreted so as also to include persons living 'as if they were [the] wife or husband' of the tenant. ${ }^{36}$

Defenders of a British-style charter have strongly criticized the approach of the Legal Committee in Ghaidan, on the basis that it would clearly have 'be[en] preferable to use the declaration of incompatibility mechanism to draw attention to the human rights breaches' in the relevant legislation. ${ }^{37}$ They point, by way of illustration, to the decision in the Committee in the parallel case of Bellinger $v$ Bellinger ('Bellinger'), in which the Law Lords relied on s 4 rather than s 3 of the HRA, after finding incompatibility between the Matrimonial Causes Act 1973 (UK) c 18 and Arts 8 and 14 of the European Convention to the extent that the Act failed to recognize the validity of the marriage of Mrs Bellinger, as a post-operative transsexual. ${ }^{38}$

The difficulty with this view is that it ignores the degree to which reliance on a remedy under $\mathrm{s} 4$, as opposed to s 3, can affect the chance of an individual plaintiff ultimately obtaining relief in different categories of case.

In a pure public law case such as Bellinger, a decision by a court to rely on s 4 of the HRA will in no way preclude someone such as Mrs Bellinger from ultimately obtaining the relief she seeks (namely, having her marriage recognized as legally valid). Because individual public law rights do not 'vest' in a way which renders them immune from legislative revision, they are always subject to potential adjustment by Parliament - both to the benefit, as well as detriment, of the individual.

In Bellinger itself, this is also exactly what happened to the status of Mrs Bellinger's marriage. Three months after the decision in Bellinger, the Lord Chancellor's department published a draft Gender Recognition Bill in July 2003, which was then introduced into Parliament in November 2003, and passed in June-July 2004..$^{39}$ The resulting Gender Recognition Act 2004 (UK) c 7 provides that any person who is aged at least 18 may make an application to a Gender Recognition Panel for a 'gender recognition certificate,' and that the Panel must, subject to certain evidentiary requirements, grant such a certificate if the person has 'liv[ed] in the other gender' for the two years preceding the application, can show that they have or have had gender dysphoria, and intend to continue to live in the acquired gender until death. In the case of married persons, such as Mrs Bellinger, it provides for an 'interim certificate' to be issued which, though it provides grounds for the nullification of a marriage, operates so as to (re)define a person's gender for the purposes of the Matrimonial Causes Act 1973 (UK) c $18 .{ }^{40}$ The Act also clearly provides, in s 9(2) that, while it does not affect things done, or events occurring, before a certificate is issued, 'it does operate for the interpretation of enactments passed, and instruments and other documents made, before the certificate is issued (as well as those passed or made afterwards)', so that Mrs Bellinger, if she applied for recognition under the scheme created by the Act, would clearly be entitled to benefit from its provisions.

In the Australian context, a pure public law case such as Al-Kateb provides a close analogue. ${ }^{41}$ While a majority of the Court in Al-Kateb held that Mr Al-Kateb was not entitled to any form of concrete judicial relief, the administrative nature of his detention meant that it was clearly open to Parliament to amend s 196 of the Migration Act1958 (Cth) in a way which altered the terms of Mr Al-Kateb's detention, either to his benefit or to his detriment. On one reading, it also meant that it was open to the relevant Minister to exercise his discretion to release Al-Kateb - which was, in fact, what the Minister did (subject to various conditions) soon after the Court's decision. ${ }^{42}$

\section{[2004] 2 AC 557.}

[2004]2 AC 557.

Ibid 572 (Lord Nicholls); 577 (Lord Steyn); 604 (Lord Rodger); 609 (Baroness Hale).

Charlesworth, above n 6, 49.

[2003] 2 AC 467.

Gender Recognition Act 2004 (UK) c 7, s 11, sch 4.

Gender Recognition Act 2004 (UK) c 7, s 5, s 11, sch 4.

(2004) 219 CLR 562.

David Marr, 'Liberty is Left in Shaky Hands When the High Court No Longer Defends It' Sydney Morning Herald (Sydney), 31 March 2005. Note that there is in fact some doubt whether this course was truly open to the Minister, on the interpretation given to s 196 of the Migration Act 1958 (UK) in Al-Kateb. No challenge was brought to the decision, however. 
A quite different position will apply in cases of a non-pure public, or civil or criminal, law nature, where constitutional commitments such as those relating to protection of property and the rule of law, will often mean that Parliament is either legally or practically prevented from retrospectively altering the rights and liabilities of parties in a particular case. ${ }^{43}$

Take Ghaidan itself as an example. If the Legal Committee in Ghaidan had relied on s 4 of the HRA, instead of s 3, the immediate result would have been that the plaintiff, Mr Godin-Mendoza, was given a choice between vacating the London flat he and his same-sex partner shared before the death of his partner and paying the much (indeed likely prohibitively) higher market rent demanded by the landlord for him to renew the lease. ${ }^{44}$ Because the case involved a dispute between two private parties (i.e. a landlord and potential tenant), the Westminster Parliament would also thereafter have had little capacity retrospectively to alter the consequences of whatever 'choice' he made, even if it wished to, given the constraints imposed by the UK's obligation under the Convention (and also the HRA itself) to respect the 'peaceful enjoyment of...possessions' ${ }^{45}$ This right of peaceful enjoyment has been interpreted by the European Court of Human Rights as conferring a general right to enjoyment of property, not just physical possession, and also as requiring that laws affecting property rights be both 'accessible, precise and foreseeable ${ }^{146}$ and strike 'a fair balance between the demands of the general interest of the community and the requirements of the protection of the individual's fundamental rights. ${ }^{17}$ Legislation directed retrospectively to granting Mr Godin-Mendoza a statutory tenancy would also likely fail even the less demanding of these two requirements under art 1 of the Protocol to the Convention for the Protection of Human Rights and Fundamental Freedoms. ${ }^{48}$ It would deprive private parties such as the defendant landlord in Ghaidan of a set of legal rights or immunities which had previously been definitively granted and settled by a court. ${ }^{49}$

Consider also a criminal case decided under the UK HRA such as $R v$ A (No 2) ('R $v A^{\prime}$ ), involving the rape-shield provisions in the Youth Justice and Criminal Evidence Act 1999 (UK) c 23 ('YJCEA'), and in relation to which the Legal Committee has also been strongly criticized for over-reliance on its power of reading down (i.e. s 3 ), as opposed to exercising its declaratory powers under s $4 .{ }^{50}$

The YJCEA specifically attempted to codify the grounds on which evidence of prior sexual history could be admitted, in part because there was a perception that the previous discretionary rape-shield regime had been largely unsuccessful in achieving its aims. ${ }^{51}$ Nevertheless, the House of Lords held that it was entitled to rely on its powers of reading down under $\mathrm{s} 3$ to interpret the relevant provisions as 'subject to the implied provision that evidence or questioning which is required to ensure a fair trial under article 6 of the Convention should not be treated as inadmissible.' The decision of the House of Lords in this case therefore not only disregarded the 'the niceties of the language of section 43(3)(c)', $; 2$ it also almost entirely ignored the broader intention of Parliament, which was to replace a discretionary regime providing for the exclusion of evidence of a complainant's prior sexual history with a rule-based or codified scheme. ${ }^{53}$ This departure from the intention of parliament will also be quite common where courts are willing to bypass

43 Ben Juratowitch, Retroactivity and the Common Law (2008).

44 [2004] 2 AC 557, 560-1.

45 Protocol to the Convention for the Protection of Human Rights and Fundamental Freedoms, opened for signature 20 March 1952, 9 ETS, art 1 (entered into force 18 May 1954)..

46 Carbonara \& Ventura v Italy (2000) VI Eur Court HR 91, [64].

47 Soering $v$ UK (1989) 11 EHRR 439, [89]. See also Carbonara \& Ventura v Italy (2000) VI Eur Court HR 91 (articulating relevant rule of law requirements); Sporrong \& Lonnroth v Sweden (1982) 52 Eur Court HR (ser A) 9 (developing the fair balance test); the discussion in Tom Allen, 'Compensation for Property Under the European Convention on Human Rights' (2007) 28 Michigan Journal of International Law 287.

48 This is likely why the remedial legislation introduced even before the decision of the House of Lords in Ghaidan purported to operate only prospectively: see Civil Partnerships Act 2004 (UK) c 3, s 81 sch 8.

49 For an exploration and critique of the potential inconsistency between a bar on legislatively-created, as opposed to judicially-created, retroactivity, see Juratowitch, above n 37; David Mead, 'Rights, Relationships and Retrospectivity: The Impact of Convention Rights on Pre-Existing Private Relationships Following Wilson and Ghaidan' (2005] Public Law 459.

50 See discussion in $R \vee A$ [2002] 1 AC 45, 59.

51 Cf Jennifer Temkin, 'Sexual History Evidence — Beware the Backlash' (2003) Criminal Law Review 217, 222 ('It was the failure of discretionary regimes to staunch the flow of sexual history evidence which prompted the enactment of $\left.\mathrm{s} 41^{\prime}\right)$.

$52 R \vee A[2002] 1$ AC 45, 68.

53 See Peter Mirfield, 'Human Wrongs' (2002) 118 Law Quarterly Review 20, 23; Jennifer Temkin, above n 45, 240. 
the text of a statute in this way, because even if judges are in such circumstances attempt in good faith to discern the intent of the legislature, they will often find that in doing so they end up rewriting, rather than giving effect, to the actual balance parliament has attempted to strike in a particular area ${ }^{54}$

While the decision can rightly be criticized on these grounds, 55 it is important to bear in mind the reason why members of the Legal Committee may have felt pressure in this case to provide a remedy under s 3 rather than s 4 of the UK HRA.

Had the Committee relied on a remedy under s 4, the direct result would have been that 14 defendants were put at risk of what in the Committee's view would have been wrongful conviction for an offence carrying a formal maximum penalty of life imprisonment, and a guideline sentencing range of 5 to 8 years, absent any aggravating circumstances. ${ }^{56}$ While hypothetically Westminster could have responded to such a decision by adopting legislation creating a right to a new trial on the part of persons convicted under the relevant provisions of the YJCEA, such legislation would in practice have been extremely unlikely. ${ }^{57}$ It would have created potentially serious delays and increases in cost in the English criminal justice system, in an area where speedy and effective prosecution is a matter of high community concern.

Knowing this, rather than facing a simple question of the 'correct' interpretation of $\mathrm{s} 3$ as opposed to $\mathrm{s} 4$, in cases such as $R v A$ and Ghaidan, the Law Lords faced an extremely difficult choice between, on the one hand, avoiding the distortion of statutory language and intent, and, on the other, ensuring justice as they saw it to individual litigants. Because judges in the common law tradition are trained to believe that there can be no right without a judicial remedy, 58 they will also be strongly predisposed in such cases to prefer the demands of justice as they see it over the demands of statutory integrity. ${ }^{59}$ This will be true in both civil and criminal cases, but particularly so in criminal cases where the common law has traditionally given common law judges broad residual responsibility for ensuring that a defendant obtains a fair trial. ${ }^{60}$

While it is not fully appreciated even in the UK, this also explains why in civil and criminal cases, despite clear calls by various members of the House of Lords to adopt a restrained approach to s $3{ }^{61}$ English courts have consistently stretched legislative language, even to the point of completely ignoring both it and much of the legislative intention which lies behind it. ${ }^{62}$

As Table 1 shows, of the 10 declarations of incompatibility made by English courts between 1999 and 2004 (and upheld on appeal), nine of those cases arose in a pure public law setting; whereas of the nine cases decided in this period under s 3 of the HRA, only two had a purely public law character.

54 See Frank Easterbook, 'Foreword: The Court and the Economic System' (1984) 98 Harvard Law Review 4. Cf Carolyn Evans and Simon Evans, Australian Bills of Rights: The Law of the Victorian Charter and the ACT Human Rights Act (2008).

55 Ibid.

56 This, at least, was the position at the time of A, and prior to the enactment of the Sexual Offences Act 2003 (UK) c 42: see $R v$ Millberry [2002] EWCA Crim 2891.

57 Any attempt directly to reverse the result as it applied only to A would very likely be constitutionally prohibited, even in the UK, by rule of law principles.

58 See, eg, Peck $v$ Jenness, 48 US 612, 623 (1849) ('A legal right without a remedy would be an anomaly in the law').

59 On the potential relevance of psychological pressures of this kind on judicial behaviour, see, eg, Steven Winter, A Clearing in the Forest: Life, Law Mind (2003).

60 See Dietrich $v$ The Queen (1992) 177 CLR 292.

61 See, eg, $R$ (Anderson) v Secretary of State for the Home Department [2003] 1 AC 837, 858 (Steyn LJ); 863 (Buxton LJ).

62 See, eg, $R \vee$ Holding [2005] 1 WLR 1040 (reading 'out' the word or from the provisions of $\mathrm{s}$ 75(1) of Representation of the People Act 1983 (UK) c 2, stating that 'no expenses shall... be incurred' unless those expenses relate to presenting to the electors a candidate or his views, and to certain forms of broadcasting or other communication, or do not exceed a prescribed limit, and therefore the relevant provision as largely inapplicable to Holding's conduct); $R(O)$ v. Harrow Crown Court [2006] 3 WLR 195, 202 (reading s 25(1) of the Bail Act 1976 (UK) c 63, providing that where a person is charged with certain categories of offense, that person should 'be granted bail...only if the court or,...the constable...is satisfied that there are exceptional circumstances which justify it', as imposing a merely evidentiary burden on an accused to show circumstances justifying release on bail, which the prosecution was then required to rebut). 
Table 1 Legislative Sequels to Judicial Decisions under the HRA

\begin{tabular}{|l|c|c|}
\hline $\begin{array}{c}\text { Nature of case } \\
\text { (expanded case sample) }\end{array}$ & $\begin{array}{c}\text { Pure public/ } \\
\text { administrative law }\end{array}$ & Civil or criminal law \\
\hline Cases decided under s 4 & 9 & $1^{*}$ \\
\hline Cases decided under s 3 & 2 & 7 \\
\hline
\end{tabular}

Of the relevant $\mathrm{s} 4$ cases, two concerned the administrative detention of mental health patients; one the administrative detention of potential terrorism suspects; two the validity of births and marriage records (one of which was the Bellinger case); one a question of tax law; one concerned civil penalties related to customs and immigration; and one, the scope of discretion enjoyed by the parole board. ${ }^{63}$ Only one case, $R v M c R,{ }^{64}$ involved a true criminal or civil law issue, and the court in that case issued a remedy which, while it purported to be a remedy under s 4, was in fact tantamount to declaration of inconsistency, rather than incompatibility. ${ }^{65}$

By contrast, of the s 3 cases, four were pure criminal law cases concerning the scope of criminal sentencing discretion; evidentiary rules or burdens of proof in criminal trials $(R v A$ was one of these cases); and the scope of terrorism-related criminal offenses ${ }^{66}$ An additional three were civil in nature and related to a claim of wrongful death under the Fatal Accidents Act 1976 (UK) c 30; proceedings for winding up in bankruptcy; and a residential tenancy dispute (namely, Ghaidan). ${ }^{6}$ Only two cases were purely public law in nature with one involving a question about the scope of parole board discretion, and one about the scope of the powers of a coroner in a coronial inquest. 68

A similar pattern can also be observed if one extends the sample of cases decided under the HRA from 2004 to $2006 .{ }^{69}$ Of the additional five cases decided in reliance on s 3 during this period, all arose in either a civil or criminal, rather than pure public law context. Three cases were criminal law cases involving a criminal conviction for incurring unauthorized election expenses; the grant of bail to those charged with serious criminal offences; and the length of a mandatory minimum term to be served by a prisoner under a life sentence. ${ }^{70}$ Two were civil cases involving a dispute about adverse possession and a claim for

$63 R(H) v$ London North and East Region Mental Health Review Tribunal [2002] QB 1 (administrative detention of mental health patients); $R(D) v$ Secretary of State for the Home Department [2003] 1 WLR 1315 (parole board discretion in respect of mental health patients); $R$ (on the application of $M$ ) $v$ Secretary of State for Health [2003] 1 WLR 1318 (representation of persons challenging administrative detention, in mental health context); Blood and Tarbuck v Secretary of State for Health (Unreported, High Court, Sullivan J, 2002 ) (registration of parentage); Bellinger [2003] 2 AC 467 (validity of marriage); R (Wilkinson) v Commissioners of Inland Revenue [2003] 1 WLR 2683 (tax deduction); International Transport Roth GmbH v Secretary of State for the Home Department [2003] QB 728 (customs-related civil penalty scheme); $R$ (Anderson) $v$ Secretary of State for the Home Department [2003] 1 AC 837 (parole board discretion); A v Secretary of State for the Home Department [2004] UKHL 56 (Unreported, Lord Bingham, Lord Nicholls, Lord Hoffmann, Lord Hope, Lord Scott, Lord Rodger, Lord Walker, Lord Hale and Lord Carswell, 16 December 2004) (administrative detention of non-citizens deemed a national security threat).

64 [2002] NIQB 58.

65 Ibid (hearing appeal against conviction for buggery). The High Court in that case not only made a declaration of incompatibility; it also granted an order for certiorari quashing the effect of the appellant's conviction, in a way which approximated an exercise of the stronger remedial power to issue a declaration of inconsistency.

$66 \quad R \vee$ Offen [2001] 1 WLR 253 (criminal sentencing); $R \vee A$ [2002] 1 AC 45 (admissibility of evidence in criminal trial); $R v$ Lambert [2001] 3 WLR 206 (burden of proof in criminal trial); A-G's Reference No 4 of 2002 [2004] UKHL 43 (Unreported, Lord Bingham, Lord Steyn, Lord Phillips, Lord Rodger and Lord Carwell, 14 October 2004) (scope of terrorism-related crimes).

67 Cachia v Faluyi [2001] 1 WLR 1966 (hurdles to civil action under Fatal Accidents Act); $R v$ Carass [2002] 1 WLR 1714 (burden of proof in bankruptcy proceedings); Ghaidan [2004] 2 AC 557 (residential tenancy dispute).

$68 R$ (Sim) $v$ Parole Board [2003] 2 WLR 1374 (power of parole board); R (Middleton) v Her Majesty's Coroner for the Western District of Somerset [2004] 2 WLR 800 (scope of coronial inquest).

69 This cut-off is designed to prevent the over-counting of remedies issued by lower courts subsequently overturned on appeal.

70 See $R$ v Holding [2005] 1 WLR 1040; $R(O) v$ Harrow Crown Court [2006] 3 WLR 195; $R$ (Hammond) $v$ Secretary of State for the Home Department [2006] 1 AC 603. 
defamation. ${ }^{71}$ By contrast, of the additional three cases decided under $\mathrm{s} 4$ in this period and not overturned on appeal, all four were pure public law cases. ${ }^{72}$

The sharpness of this contrast between the kinds of case decided under s 3 and s 4 also seems extremely difficult to explain, other than by reference to the dilemma courts face under a British-style charter between respecting the bounds of their remedial authority and ensuring justice, as they see it, to individual litigants.

There was, for example, no systematic difference between the relevant cases when it came to the kind of relief sought by the parties. In the 14 cases decided under s 4 between 1999 and 2006, the court was urged by either individual rights claimants or the state to grant relief in terms of s 3 (or an equivalent coercive remedy) in at least half of the relevant cases. ${ }^{73}$ There was also no difference between the two sets of cases in terms of the time at which the legislation under challenge was enacted, and thus in the degree to which Westminster could be assumed to have considered the HRA as part of the legislative process. In both the 14 cases decided under s 4 and 15 cases decided under s 3 from 1999 to 2006, there were only two cases involving legislation passed after the enactment of the HRA. ${ }^{74}$

What is instead clear from this pattern is that a British-style charter creates extremely strong pressure on courts, at least in an important sub-set of cases, to ignore the bounds of both statutory meaning and intention. The limited experience to date at the state and territory level in Australia also does nothing to refute this understanding about the link in civil and criminal cases between weak remedies and pressures toward statutory distortion.

Take a case such as SI bhnf CC v KS bhnf IS, decided by the ACT Supreme Court under the ACT Human Rights Act 2004 (ACT) ('ACT HRA'). ${ }^{75}$ The case involved a challenge to the making by a Registrar of the ACT magistrates' court of a 'final' protection order, under the Domestic Violence and Protection Orders Act 2001 (ACT) ('Protection Act'). The terms of s 51A of the Protection Act provided that an interim protection

71 See Beaulane Properties Ltd v Palmer [2006] Ch 79 (scope of doctrine of adverse possession); Culnane v Morris [2006] 2 All ER 149 (defence to defamation action).

72 Two concerned issues relating to immigration, specifically the rights of citizens with non-citizen family members to gain priority access to public housing and the right of persons subject to immigration control to marry: see $R$ (Morris) $v$ Westminster City Council [2006] 1 WLR 505 (rights of citizens with non-citizen dependent children); R (Gabaj) v First Secretary of State (Unreported, Administrative Court, 28 March 2006) (rights of citizens with non-citizen pregnant spouse). One concerned the eligibility for a tax-concession: see $R$ (Hooper) v Secretary of State for Work and Pensions [2003] EWCA Civ 875. A fourth declaration was also issued in respect of rights of access to public housing, but overturned on appeal: see $R$ (Baiai) $v$ Secretary of State for the Home Department [2006] 3 All ER 608; [2008] All ER (D) 411.

$73 \quad R(H) v$ London North and East Region Mental Health Review Tribunal [2002] QB 1, 8 (argument by appellant); $R v M c R$ [2002] NIQB 58 (seeking declaration of incompatibility, but with effect of declaration of inconsistency or reading down); International Transport Roth GmbH v Secretary of State for the Home Department [2003] QB 728, 758 (argument by Secretary, not opposed by appellant); $R$ (Wilkinson) $v$ Commissioners of Inland Revenue [2003] 1 WLR 2683, 2687 (argument by appellant); $R$ (Anderson) $v$ Secretary of State for the Home Department [2003] 1 AC 837, 849; Bellinger [2003] 2 AC 467, 471; R (Hooper) v Secretary of State for Work and Pensions [2003] 1 WLR 2623, [ 2]. In $R(D) v$ Secretary of State for the Home Department, [2003] 1 WLR 1315 and R (Morris) v Westminster City Council [2006] 1 WLR 505, while the petitioners sought relief under the UK HRA only in terms of s 4, they also sought more concrete relief under the Mental Health Act 1993 and Local Government Act 2000 (UK) c 22, respectively. For cases in which individuals sought only to obtain a remedy purely in terms of s 4, and no other concrete remedy, see Blood and Tarbuck v Secretary of State for Health, (Unreported, High Court, Sullivan J, 2002); R (on the application of M) $v$ Secretary of State for Health [2003] 11 Med L Rev 246; A v Secretary of State for the Home Department [2004] UKHL 56 (Unreported, Lord Bingham, Lord Nicholls, Lord Hoffmann, Lord Hope, Lord Scott, Lord Rodger, Lord Walker, Lord Hale and Lord Carswell, 16 December 2004). In each case, this can also be explained by quite specific features of the case, such as the symbolic rather than practical significance of the relief sought ( $M$ case), or a strategic concern to avoid making a demand for immediate relief ( $A v$ Secretary). Absent publication of the judgment, it is currently impossible to determine the nature of the relief sought in $R$ (Gabaj) v First Secretary of State (Unreported, Administrative Court, 28 March 2006).

74 In the context of s 4, see International Transport Roth $G m b H$ v Secretary of State for the Home Department [2003] QB 728; A v Secretary of State for the Home Department [2004] UKHL 56 (Unreported, Lord Bingham, Lord Nicholls, Lord Hoffmann, Lord Hope, Lord Scott, Lord Rodger, Lord Walker, Lord Hale and Lord Carswell, 16 December 2004). In the case of s 3, see $R$ v A [2002] 1 AC 45; A-G's Reference No 4 of 2002 [2004] UKHL 43 (Unreported, Lord Bingham, Lord Steyn, Lord Phillips, Lord Rodger and Lord Carswell, 14 October 2004) .

75 (2005) 34 Fam LR 468. 
order 'becomes a final order' if a respondent does not return an endorsement copy of an interim order seven days prior to the return date for the final order. Because the respondent was not aware of this, and did not return the order by this time, the Registrar granted a final order, valid for 12 months, without giving the respondent an opportunity to challenge its basis.

Higgins CJ chose to 'read down' the terms of s 51A, so that, where an endorsement copy of an interim order was not returned, the magistrate had a discretion, rather than obligation, to enter a final order, and a further discretion to set aside a final order if sufficient cause was shown. In doing so, Higgins CJ clearly ignored a large amount of the language in the relevant section, as well as at least part of the Legislative Assembly's intention of creating a more victim-protective system of protective orders. ${ }^{76}$

Because of this, the decision has been strongly criticized by scholars such as Hilary Charlesworth for adopting a remedial approach which is 'unsatisfactory....from the perspective of the promotion of a human rights dialogue'. ${ }^{77}$

The difficulty with this criticism, however, is that it ignores the degree to which Higgins CJ was in fact responding to the same kind of dilemma faced by the UK courts in Ghaidan and $R v A$ : namely, the dilemma of whether to prioritise respect for statutory language and intent, or instead the protection of individual rights (as he saw it) in the particular concrete case.

Had Higgins CJ declined to engage in radical reading down of the kind he did (or in the alternative, to invalidate the relevant legislation for inconsistency with Ch III of the Constitution), but instead relied on the declaratory power open to him under s 30 of the ACT HRA, there would have been a very real danger of ongoing - potentially serious - injustice to the respondent, at least as the court saw it. Until the ACT Legislative Assembly saw fit to revisit s 51A of the Act, or the 12 month term of the order issued against him expired, the respondent would have faced a very real danger of criminal liability (on strict liability basis) for breach of an order, which he argued should never have been issued in the first place. The maximum penalty for such a breach was, in turn, a fine of $\$ 50000$, or up to five years' imprisonment. ${ }^{78}$

Under a Canadian-style statutory charter, this same dilemma need not arise, because courts have the power to invalidate legislation for inconsistency with individual rights, and therefore have no need to rely on a power of reading down, in order to achieve justice as they see it in cases such as $R v A$ or SI bhnf CC.

This does not mean that under a Canadian-style rights charter, the danger of statutory distortion will be zero. In cases, such as Ghaidan, where legislation is arguably under- rather than over-inclusive, there will still be some danger of statutory distortion, where courts lack the kind of power enjoyed for example by the SCC under the Canadian Charter, to 'read-in' or insert language into a statute. ${ }^{79}$ This is also one reason why, minimalist arguments aside, there could be advantages to adopting a charter of rights by constitutional rather than statutory means. From a minimalist perspective, however, because this option of a more entrenched charter is ruled-out from the outset, the question is whether, relative to a UK-style charter, a Canadian-style statutory charter is likely to reduce the danger of statutory distortion.

The answer to this question is almost certainly yes - because, instead of the danger of statutory distortion arising in all civil and criminal cases, it will arise, at most, under a Canadian-style charter in a sub-set of these cases involving legislation that the court views to be under- rather than over-inclusive.

\section{B Ordinary dialogue and the British model in Australia}

At a federal level in Australia, the danger of statutory distortion under a British-style rights charter, relative to that under a Canadian-style charter, is also likely to be even more acute than in the UK itself, given the potential constraints imposed by Ch III of the Constitution. 80

There is clearly substantial room for debate about what Ch III implies for the validity of a scheme of weak remedies at a federal level. ${ }^{81}$ One possibility is that Ch III means that no Australian court can

76 For discussion of the relevant legislative intent, see (2005) 34 Fam LR 468, 483.

77 Charlesworth, above n 6, 50.

78 Domestic Violence and Protection Order Act 2001 (ACT) s 34 (repealed).

79 See, eg, Schachter v Canada [1992] 2 SCR 679.

80 In the ACT in particular, the interpretive pressure imposed by Ch III may be equally as great because the relevant constraints apply to at least some degree: see SI bhnf CC (2005) 34 Fam LR 468, 485-6; Stefanie Wilkins, 'Constitutional Limits on Bills of Rights Introduced by a State or Territory' (2007) 35 Federal Law Review 431.

81 Cf Geoffrey Lindell, 'The Statutory Protection of Rights and Parliamentary Sovereignty: Guidance from the United Kingdom?' (2006) 17 Public Law Review 188, 204-7 (arguing in favour of the existence of a 'matter' and Commonwealth judicial power in these circumstances); The Hon Michael McHugh, 'A Human Rights Act, 
validly issue a UK-style declaratory remedy in the exercise of federal jurisdiction, because such a remedy would be wholly unconnected from any 'matter' for the purposes of ss 75, 76 or 77 of the Constitution, or less likely, incompatible with the exercise of judicial power, and thus wholly inconsistent with Ch III.A second possibility is that state and federal courts would have jurisdiction to issue such declarations, but the High Court would be limited in its ability to hear appeals against the decision to issue or refrain from issuing a declaration of incompatibility. Section 73 of the Constitution limits the Court's appellate jurisdiction to appeals from 'judgments, decrees, orders, and sentences', and on one view, a declaration of incompatibility might not be sufficiently 'definitive of legal rights' to qualify as a judgment for these purposes. ${ }^{82}$

A third possibility is that the Court might lack jurisdiction to hear an appeal from the decision to grant a declaration of incompatibility in only a sub-set of cases, in which neither party to the appeal sought to pursue reading-down as an alternative remedy. In such cases, the Court might find that it was being asked to exercise a power outside 'the judicial power of the Commonwealth' conferred by Ch III. ${ }^{83}$

A fourth and final possibility is that the Court might consider a system of weak remedies to be wholly consistent with both the specific and general requirements of Ch III.

Given the Court's existing approach in this area, the most likely outcomes seems to be that the Court will adopt either the third or the fourth approach namely, find that, at most, Ch III precludes the Court from hearing certain appeals against the making of a declaration of incompatibility and in no way generally impairs the functioning of a UK-style rights charter.

The first approach seems particularly unlikely from both a doctrinal and comparative perspective.

In Kable $v$ DPP, 84 the High Court set out a number of factors relevant to determining whether a power is judicial or not, including: whether the exercise of the power turns on the existence of any breach of antecedent law or legal obligation, involves the resolution of 'an actual or potential controversy as to existing rights and obligations is involved'; allows for the exercise of discretion and has traditionally been exercised by courts; legislators or members of the executive; 85 and a declaration of incompatibility clearly satisfies at least the first, third and fourth of these requirements. ${ }^{86}$

From a comparative perspective, there is also good evidence that the grant, by courts, of a declaration of incompatibility is compatible with their otherwise continuing to behave like, and be respected as, impartial common law legal tribunals. In the UK, English courts have now issued close to 20 declarations of incompatibility which have been upheld on appeal, without any noticeable change in the broader functioning of the English judiciary. ${ }^{87}$ In New Zealand, the New Zealand Court of Appeal has since 2000 asserted an equivalent power to make an indication of inconsistency, ${ }^{88}$ without any widespread adverse effects on the public standing of the Court or lower courts. ${ }^{89}$

Providing a national rights charter incorporates certain features of the ACT HRA and the Victorian Charter regarding the role of the Attorney-General (or relevant Minister), the second approach also seems like unlikely. ${ }^{90}$

the Courts and The Constitution' (Speech delivered at the Australian Human Rights Commission, Sydney, 5 March 2009) 20; Dominique Dalla-Poza and George Williams, 'The Constitutional Validity of Declarations of Incompatibility in Australian Charters of Rights' (2007) 12 Deakin Law Review 1 (arguing that such a scheme would be valid in its entirety); James Stellios, 'State/Territory Human Rights Legislation in a Federal Judicial System' (2008) 19 Public Law Review 52 (arguing that, while the better view is such a model is compatible with Ch III, existing High Court precedent raises substantial doubts about the question).

82 Minister for Works (WA) v Civil and Civic Pty Ltd (1967) 116 CLR 273, 277 (Barwick CJ) (holding that '[i]t is of the essence of a judgment within the meaning of the Constitution that it is binding upon parties and definitive of legal rights'). See also discussion in Mellifont v A-G (QId) (1991) 173 CLR 289.

86 It will certainly involve the application of existing human rights standards, established by both national and international law. English precedent confirms that it turns on an exercise of discretion by a court: see, eg, Bellinger [2003] 2 AC 467, 482 (Lord Nicholls). The making of a declaration of incompatibility also involves an exercise of power which, while to some degree novel in a judicial setting, has no historical link to the exercise of either legislative or executive power. 
In the ACT, s 33 of the ACT HRA provides that the Attorney-General has two duties consequent on the making by a territory court of a declaration of incompatibility. First, the Attorney-General must present a copy of the declaration of incompatibility to the Legislative Assembly within six sitting days of receiving a copy of the declaration; and second, within six months of that date, he or she must prepare a written response to the declaration of incompatibility and present it to the Legislative Assembly. In Victoria, s 37 of the Victorian Charter imposes almost identical duties on the Minister responsible for the statutory provisions in respect of which the declaration is made, with the additional requirement that the Minister cause his or her written response to the declaration to be published in the Government Gazette. In both the ACT and Victoria this means that the making, or non-making, of a declaration of incompatibility has direct consequences for the legal duties of federal or state Ministers. This connection also ensures that any request of a party, asking the Court to issue such a remedy, involves a question with the decisiveness and concreteness necessary for the Court to exercise jurisdiction under $\mathrm{s} 75$ of the Constitution.

Under the UK HRA this is not the case, because the making of a declaration of incompatibility enlivens only a special legal power, rather than duty, on the part of the relevant minister to amend the operation of the relevant legislation. ${ }^{91}$ From a domestic legal standpoint, the duty of a Minister of the Crown to a respond to a declaration of incompatibility is purely political rather than legal. There is thus a crucial difference, from the perspective of Ch III of the Constitution, between the operation of the current Australian state charters and the UK HRA. ${ }^{92}$

Even if the Court were to reject this argument, that the decision to grant a declaration of incompatibility itself involves a 'matter,' it also seems more likely to endorse the third, as opposed to second, approach to the Constitutionality of declarations of incompatibility- i.e. to hold that, in most cases at first instance, the grant of a remedy is incidental to what is clearly a constitutional matter: namely, a dispute as to whether a particular statute should be read down so as to conform to a particular interpretation of charter rights. ${ }^{93}$ Likewise, on an application for special leave to appeal against the making of such a declaration, the Court would likely find that a challenge to the grant (or refusal) of such a declaration was sufficiently connected - in the negative - to 'definitive' resolution of such a matter, to constitute a 'judgment' for the purposes of the Court's appellate jurisdiction under s73 of the Constitution. ${ }^{94}$

When a court is faced with a dispute of this kind, it may decide to deny relief to a rights claimant for two quite distinct reasons: either because it does not believe that the statute in question unjustifiably limits rights; or because it believes that the language of the statute prevents it from relying on reading down as a remedy for an identified rights violation. Given this, a declaration of incompatibility mechanism plays an essential role in helping a court explain to a rights plaintiff how it has resolved their claim, in the event that it does so in a manner adverse to them. The making of a declaration of incompatibility expressly indicates to the plaintiff that they have succeeded on the merits but failed at a remedial stage; whereas the absence of such a declaration (combined with the absence of or reading down as a remedy) indicates that they have failed on the merits.

Without the ability to make such a declaration, courts with only weak remedial powers will, by contrast, often find it extremely difficult to provide this guidance to plaintiffs, without trenching on issues that are wholly unnecessary for them to decide. ${ }^{95}$ From a rule of law perspective, the ability of a court to explain how it has resolved a matter will also clearly be integral to its resolution of the matter itself.

Even if the Court were to accept this argument, however, it might still find that it is limited in its ability to hear some appeals from the making of a declaration of incompatibility. In some sub-set of cases on appeal, neither the applicant nor the respondent may wish to pursue reading down as an alternative remedy. Having won at first instance on the merits, a rights plaintiff, particularly in a pure public law

Cf Stellios, above n 74, 65-8 (expressing doubts on this question). Cf Saffron v R (1953) 88 CLR 523 (Dixon CJ).

95 See, eg, the view of the majority in Quilter v Attorney General [1998] 1 NZLR 523; aff'd [1996] NZLR 481. 
case, may not wish to disturb the lower court's finding by way of a cross-appeal. The state, as respondent, may also lack an interest in arguing for reading down as an alternative remedy. 96

In such cases, the absence of a claim for reading down would almost certainly mean that, if the Court were to reject the general argument about ministerial obligation, it would also reject an application for special leave to appeal. The appeal in question would have no direct consequence for the legal rather than political imperative facing Parliament (or state Parliaments) to respond to a lower court decision. As such, it would clearly involve a request for the Court to exercise a form of judicial power beyond the scope of Commonwealth judicial power.

Such cases would, of course, very likely constitute a fairly small fraction of the total number of cases ultimately arising under a national rights charter. However, the mere possibility of a case falling into this category would be sufficient to create some additional pressure for state or federal courts to avoid relying on a declaration of incompatibility in Australia, relative to the UK.

The mere existence of doubt - and debate - surrounding the constitutionality of a declaration of incompatibility mechanism under Ch III among commentators as distinguished as former Chief Justice Brennan and former Justice $\mathrm{McHugh}^{97}$ would also, by itself, likely be sufficient to create additional pressure in Australia, relative to the UK, towards statutory distortion, at least in cases at first instance.

Imagine an early case in which, in response to an identified rights violation, a state court or federal court at first instance was weighing whether to issue a declaration of incompatibility, or rather to engage in a process of (so called) reading down.

A decision to rely on reading down might well be criticized by the High Court for going too far in stretching a court's powers of interpretation. The Court, however, would almost certainly uphold the lower court's decision as constitutional, and also find that it had power to set aside such a decision on appeal. ${ }^{98}$ The lower court therefore could not be criticized for asserting either a power which it did not in fact enjoy under the Constitution, or advancing its own interpretation of the charter at the expense of the Court.

If a lower court judge were, on the other hand, to rely on a declaration of incompatibility, the judge's decision might be subject to two far more serious criticisms. The High Court might, if it were to adopt the first approach to the constitutionality of a UK-style charter in Australia, find that the lower court had acted wholly contrary to the Constitution. Alternatively, if the Court were to prefer the second or third approach, it might find that, while the lower court had not itself contravened Ch III, its decision did not constitute a judgment for the purposes of s 73, or the subsequent actions of the parties had mooted the basis for exercising Commonwealth judicial power, and was thus not subject to an appeal to the Court. If this were the case, the lower court's decision might then be criticized by the broader legal community as constituting an unnecessary assertion of unilateral power to interpret the charter at the expense of the High Court.

Given this, it would clearly make sense, pending clarification of the issue by the High Court, for a lower court judge, who was in any way concerned about the potential for criticism of his or her decisions, to avoid reliance on a declaration of incompatibility. In the eyes of most commentators, a judge's failure to appreciate the constitutional limits on their authority, or the potential undesirable constitutional consequences of their decisions, will clearly be more a serious lapse in judgment than the over-zealous exercise of an actual interpretive discretion. 'Reading down' a statute, even to the point of ignoring its language and intent, will therefore tend to be the much more cautious path for a trial judge in most early charter cases.

If this is indeed the case, the result will be that, in the crucial formative years of a charter's early operation, Parliament is not only deprived of the hoped-for power of non-implementation under a

96 While in some cases the government may view reading down as preferable to a declaratory remedy, because for example it is less politically salient and therefore costly, in others it may well regard such a remedy as less desirable on account of the fact that it deprives Parliament of the power of non-implementation.

97 See McHugh, above n 74; Sir Gerard Brennan, 'Introduction to Human Rights Law: Seminar — Part II' (2007) 81 Australian Law Journal 248, 258.

98 The one potential caveat to this is that the Court might find that, in some cases, reliance on a super-extended power of reading down so as to 'read in' curative language into legislation might constitute an exercise of legislative, rather than judicial, power in a manner inconsistent with Ch III: see McHugh, above n 74, 27-30. This, however, seems unlikely, given the degree to which it assumes a realist approach by members of the Court to the process of reading down, and therefore the extent to which it would also likely be correlated with a more realist/functionalist approach to the separation of powers on the part of the Court. 
British-style rights charter. By reason of statutory distortion, it will also be deprived, to an even greater degree than Westminster has been to date in s 3 cases, of the more general ability to engage in dialogue via the use of ordinary legislative means.

\section{CANADIAN STYLE RIGHTS CHARTERS AND JUDICIAL DEFERENCE}

\section{A The CBOR and the danger of overly weak judicial review?}

For some, modelling a national rights charter on a Canadian-style statutory charter raises the distinct difficulty that such a charter might turn out to be too minimalist in the change it achieves regarding the protection of individual rights in Australia. ${ }^{99}$

Under the CBOR itself, the SCC, for example, has invalidated legislation for inconsistency with rights on only one occasion since $1960 .{ }^{100}$ Because the Court has read the language in s 1 of the CBOR, providing that certain rights should 'continue to exist', as restricting the scope of the CBOR to those rights already recognized in 1960, the CBOR has had little potential to promote an evolving dialogue about rights in Canada. The concern is, therefore, that if a national rights charter were modelled on the CBOR, rather than lead to a truly minimalist form of rights reform, it could lead to no reform at all.

To a large extent, however, this concern overlooks the fact that sustained academic criticism of the SCC's approach to the interpretation of the CBOR, as too deferential, means that, for the High Court, that approach would in all likelihood serve as a strong anti-precedent, rather than precedent, in the interpretation of any $C B O R$-style charter in Australia. ${ }^{101}$ By itself, this would go a substantial way towards ensuring that any Canadian-style rights charter adopted in Australia will promote some form of constitutional change in regard to the protection of rights. The very different international human rights law context in Australia today, compared to when the $C B O R$ was enacted, also further increases this likelihood of a statutory rights charter in Australia promoting at least some minimal constitutional change.

In 1960 neither of the two covenants comprising the 'international bill of rights' - ie the International Covenant on Civil and Political Rights ${ }^{102}$ and the International Covenant on Economic, Social and Cultural Rights $^{103}$ - had been drafted, let alone come into force. Not surprisingly, given this the SCC regarded the $C B O R$ as addressed to protecting a fairly narrow set of common law rights rather than human rights more broadly. Now, by contrast, the international bill of rights forms a crucial backdrop to all modern rights charters. Governments have routinely pointed to the international bill of rights, and the obligations it creates as a reason to adopt a domestic rights charter. ${ }^{104}$ Foreign courts have accordingly interpreted

99 For arguments in favour of a more entrenched Canadian-style rights charter in Australia, see, eg, Castan Centre for Human Rights Law, Submission to the National Human Rights Consultation (2009) [3.4], [6.1].

100 This is despite the fact that, for more than 20 years, the CBOR was the only national rights charter in operation in Canada. After the enactment of the Charter, there were comparatively few cases in which the CBOR had the potential to provide broader protection for individual rights than the charter. One potential exception is in the case of the right to property: see, eg, David Johansen, 'Property Rights and the Constitution' (Background Paper No BP-268E, Parliamentary Research Branch, Library of Parliament, Canada, 1991).

101 See, eg, Michael Taggart, 'Tugging on Superman's Cape: Lessons from Experience with the New Zealand Bill of Rights Act 1990' (1998] Public Law 266, 275 (suggesting that 'the dismal performance of the Canadian judiciary with the "ordinary statute" 'Canadian Bill of Rights 1960' was common knowledge in New Zealand legal circles and has been viewed there as 'an object-lesson to avoid repeating').

102 International Covenant on Civil and Political Rights, opened for signature 16 December 1966, 999 UNTS 171 (entered into force 23 March 1976) ('ICCPR').

103 International Covenant on Economic, Social and Cultural Rights, opened for signature 16 December 1966, 999 UNTS 3 (entered into force 3 January 1976) ('ICESCR').

104 For the influence of the ICCPR on the drafting of the Canadian Charter, eg, see John Claydon, 'The Use of International Human Rights Law to Interpret Canada's Charter of Rights and Freedoms' (1987) 2 Connecticut Journal of International Law 349 (1987); Lorraine E Weinrib, 'Canada's Charter: Comparative Influences, International Stature' in Debra M McAllister and Adam M Dodek (eds), The Charter at Twenty: Law and Practice (2002) 495; for the influence of the ICCPR on the drafting of the NZBOR, see Kenneth J Keith, "'Concerning Change": The Adoption and Implementation of the New Zealand Bill of Rights Act 1990' (2000) 31 Victoria University of Wellington Law Review 721, 743; Paul Rishworth, 'The Inevitability of Judicial Review under "Interpretive" Bills of Rights: Canada's Legacy to New Zealand and Commonwealth Constitutionalism' (2004) 23 Supreme Court Law Review 233, 255; and for the influence of both the ICCPR and ICESCR on the drafting of the 1993 Constitution of the Republic of South Africa, which carried over to a substantial degree into the 1996 Constitution, see, eg, Anton J Steenkamp, 'The South African Constitution of 1993 and the Bill of Rights: An Evaluation in Light of International Human Rights Norms'(1995) 17 Human 
those charters so as to give broad effect to any international consensus surrounding human rights. ${ }^{105}$ In Australia, the High Court's existing willingness to consider international human rights norms in various common law and statutory contexts also suggests that its approach to the interpretation of a national rights charter would likely be similar. ${ }^{106}$

If a rights charter were enacted pursuant to Parliament's power over external affairs in s 51(xxix) of the Constitution, this likelihood of the Court adopting international human rights understandings as a starting point for interpretation, under a national rights charter, would seem even greater. In this case, rather than simply helping promote a more morally attractive or pragmatically informed reading of particular rights, 107 a decision by the Court to give some weight to international human rights understandings could be crucial to the ongoing validity of a rights charter. ${ }^{108}$

\section{B A charter and the danger of overly strong judicial review?}

Realistically, the far greater danger under any Canadian-style, British-style, or indeed any rights charter in Australia, whether statutory or Constitutional in status, is that the High Court will tend to interpret such a charter in a way that gives too little, rather than too much, deference to parliamentary judgments about the scope and priority given to particular rights, and thereby also leads to an overly maximalist, rather than minimalist, form of constitutional change regarding the protection of human rights. ${ }^{109}$

In Canada, under the Canadian Charter in particular, it has certainly been the experience that deference by the SCC in second look cases has played a crucial role in avoiding the dangers of strongform judicial review. In first look cases, the SCC has taken a largely non-deferential approach to the interpretation of the Charter, which leaves little room for judgments about the meaning of Charter rights by Parliament or provincial legislatures. Section 33 of the Charter, or the so-called 'notwithstanding clause', which gives the Canadian Parliament and provincial legislatures broad formal power to engage in dialogue with the SCC by suspending the operation of most Charter rights has also almost never been used for that purpose. In the 37 years in which the Charter has been in operation, there has been only one case in which the notwithstanding clause has been used to override a decision by the Canadian Supreme Court under the Charter. ${ }^{110}$ That instance involved the SCC's decision in Ford v. Quebec (AttorneyGeneral), 111 and the decision by the Quebec legislature to reinstate a preference for French-only, as opposed to bilingual, signs in the province. ${ }^{112}$ Parliament has never invoked section 33 of the Charter, and provincial legislatures have used it only fifteen times in addition to its usage in connection with Ford. Twelve of those further instances also involved Quebec. ${ }^{113}$

Rights Quarterly 101; John Dugard, 'International Law and the South African Constitution' (1997) 6 European Journal of International Law 77.

105 For cases in the United Kingdom prior to the enactment of the HRA relying on transnational rights norms see, eg, Waddington v Miah [1974] 1 WLR 683, 694; Reg v Home Secretary; Ex parte Brind [1991] 1 AC 696, 747-8; in Canada see, eg, Re Mitchell and the Queen, (1983) 42 OR (2d) 481.

106 See, eg, Dietrich $v$ The Queen (1992) 177 CLR 292, 306; Mabo v Queensland (No 2) (1992) 175 CLR 1, [126]; Minster for Immigration and Ethnic Affairs v Teoh, (1995) 183 CLR 273. See also Greg Cranwell, 'Treaties and Australian Law: Administrative Discretions, Statutes and the Common Law' (2001) 1 Queenland University of Technology Law and Justice Journal 49.

107 On moral desirability, see, eg, Eric A Posner and Cass R Sunstein, 'The Law of Other States' (2006) 69 Stanford Law Review 131; Jeremy Waldron, 'Foreign Law and the Modern Ius Gentium' (2005) 119 Harvard Law Review 129; and on pragmatically informed, see, eg, Mark Tushnet, 'The Possibilities of Comparative Constitutional Law' (1999) 108 Yale Law Journal 1225; Rosalind Dixon, 'George Winterton: A Friend to Students and Foreign Law' in Memorial Volume in Honour of George Winterton (Forthcoming 2009).

108 Cf Re Certification of the Constitution of the Republic of South Africa 1996 (10) BCLR 1253 (CC) [43].

109 For critical commentary on the possibility of dialogue without such deference, see, eg, Waldron, 'Models' above $n$ 23. See also Allan, above $n 2$.

110 See Tsvi Kahana, 'The Notwithstanding Mechanism and Public Discussion: Lessons from the Ignored Practice of Section 33 of the Charter' (2001) 44 Canadian Public Administration 255, 256-8.

111 [1988] 2 SCR 712 ('Ford').

112 See An Act to Amend the Charter of the French Language, SQ 1988, c 54, s 10 ('Bill 178'). Thereafter, the Quebec legislature repealed its own attempt at dialogue by passing legislation designed to give much broader effect to the decision of the SCC in Ford, suggesting that a more narrowly tailored alternative to French-only signage laws would be laws requiring French to be 'present and predominant' on all signs. See An Act to Amend the Charter of the French Language, SQ 1993, c 40, s 18 ('Bill 86').

113 See Kahana, above n 114. 
For this reason, as I have argued elsewhere, the key to the achievement of a weaker form of judicial review in Canada, as compared to (say) the US, has been the greater willingness of the Canadian, as compared to the US Supreme Court, to defer to legislative attempts to narrow certain decisions of the Court, giving an expansive view of some rights as compared to other rights or interests. ${ }^{114}$ I have shown, for example, that of the five instances between 1982 and 2005 in which the Canadian Parliament or a provincial legislature sought to narrow the effect of the SCC's interpretation of the Charter, and the Court was subsequently asked to rule on the validity of that sequel, four involved a decision by the Court not only to uphold the relevant sequel, but also to some degree to defer to the legislative constitutional judgments implicit in such sequels. ${ }^{115}$ In only one instance in the more than 20 years of litigation under the Charter - in Sauvé v Canada (Chief Electoral Officer) ${ }^{116}$ - has the SCC actively refused to uphold a legislative sequel in its entirety. This decision by the Court in Sauvé II also involved one of the few occasions in which a majority of the Court was willing explicitly to reject the idea of deference to the Canadian Parliament in second look cases. ${ }^{117}$

From this perspective, a key challenge for proponents of a minimalist charter in Australia will also clearly be to determine how best to encourage the High Court, in its interpretation of any Canadian-style statutory rights charter, to emulate this particular aspect of the SCC;'s approach to Canada's more entrenched rights Charter.

An equally important challenge will also be to encourage Parliament to follow the lead of the Canadian Parliament, and Canadian provincial legislatures, in enacting the kind of legislative sequels necessary for such a model of deference-based dialogue to succeed.

In the latter context in particular, comparative experience further suggests the chances of success will tend to be lower, rather than higher, under a British-style charter, with its attendant dangers of statutory distortion, than under either a statutory or entrenched Canadian-style charter.

Comparison between British and Canadian experience in this area also suggests that achieving this will ultimately be less, rather than more, likely under a charter that confers only weak remedies on courts, than under a charter - even a constitutionally entrenched one -that gives courts broader, or stronger remedial powers.

In the UK, among those cases decided by the courts under s4 of the UKHRA, and therefore most public law cases, at least 2 cases met with a legislative response evidencing direct forms of disagreement, or dialogue. ${ }^{118}$ These 2 cases, Roth and Anderson, further represent a very large proportion - if not all - of the cases in which dialogue by the legislature could reasonably have been expected following reliance by British courts on s. 4 of the HRA. Together, they represent 2 out of the 5 -or $40 \%$ - of cases during the relevant period decided under s 4 at the ECA or HL level. Cases in which a declaration of incompatibility was made at a lower court level and no appeal was brought by the government, almost certainly involved results with which the government -or legislative majority - had no major disagreement, and therefore where the absence of any legislative sequel evidencing disagreement with lower court decisions is thus largely irrelevant to assessing the extent to which the legislature in the UK is willing to engage actively in dialogue. ${ }^{119}$ Even more strikingly, they represent a full $100 \%$ percent of those cases decided at an appellate level in which the government ultimately sought to uphold the compatibility of the relevant legislation with the European Convention.

A quite different pattern or rate of legislative follow-up to court decisions has occurred, in the UK, the context of the predominantly civil and criminal cases decided under s 3 of the HRA, where out of 9 cases decided between 1999 and 2004, only one has been followed by a legislative response evidencing any

$114 \overline{\text { Dixon, 'Charter Dialogue', above n } 7 .}$

115 See, eg, $R$ v Darrach [2000] 2 SCR 443; Winko v British Columbia (Forensic Psychiatric Institute) [1999] 2 SCR 625; $R$ v Hall [2002] 3 SCR 309; Canada (AG) v JTI-Macdonald Corp [2007] 2 SCR 610.

116 See Canada Election Act, RSC 1985, c E-2 (as amended by An Act to Amend the Canada Elections Act, SC 1993, c 19, s 23(2)); Sauvé v. Canada (Chief Electoral Officer) [2002] 3 SCR 519 ('Sauvé II').

117 See, eg, Sauvé II [2002] 3 SCR 519, [8]-[9].

118 ( International Transport Roth GmbH v. Secretary of State for the Home Department, [2003] QB 728 and $R$ (Anderson) v. Secretary of State for the Home Department, [2003] 1 AC 837),

119 See e.g. Re McR, or R (on the application of M) V. Secretary of State for Health, [2003], 1 W.L.R. 1318, Blood \& Tarbuck v. Secretary of State for Health (Unreported, High Court, 2002), or R. (H.) v. London North and East Region Mental Health Review Tribunal, [2002] Q.B. There will, of course, be some cases where a decision not to appeal is strategic, rather than a sincere indication of agreement. The four cases decided at a lower court level in the UK in this period seem far from this kind of case, however. The government ultimately conceded the question of incompatibility in all four cases, either at the initial hearing or afterward. 
form of direct disagreement. This is also particularly striking given that in six out of nine of these cases, the government sought actively to defend the compatibility of the relevant legislation both at first instance and on appeal; and that in several cases, the "law and order" priorities of the government would seem strongly have pointed toward parliament having an interest in engaging in dialogue with the courts. ${ }^{120}$

In Canada, by contrast, there has been a consistent willingness on the part of Parliament and provincial legislatures to enact "dialogic" sequels in response to both public and non-pure public law cases, even under the Charter.

The SCC invalidated legislation for inconsistency with the Charter on 54 distinct occasions between 1982 and 2005, and in 13 of those cases, the Canadian Parliament or provincial legislatures responded by enacting legislation some clear and direct form of legislative disagreement with the SCC about the proper balance to be struck between rights and interests in a particular area. Among those 13 cases, while 3 were pure public law cases involving the voting rights and the regulation of elections, ${ }^{121} 10$ involved legislation of a criminal (or at least quasi-criminal) character. ${ }^{122}$

It is also quite striking, in this context, that among these 13 legislative sequels, 12 were enacted by Canadian legislators in simple reliance on their ordinary legislative power, under s1 of the Charter, to impose limitations on rights that are 'reasonable and justifiable in a free and democratic society'. ${ }^{123}$ Because there is a quite real risk that when a legislative sequel is enacted on this basis, the SCC may find that it ought to have been passed in reliance on the express power of override found in s33 of the Charter, and is thus invalid, the rate at which Canadian legislators have been willing to enact such sequels may in fact tend to understate the more general willingness of legislators to engage in dialogue under a less entrenched Canadian-style charter.

\section{CONCLUSION}

Minimalism when it comes to potential changes to the relationship between the High Court and federal Parliament is, of course, far from the only criterion by which proposals for a national rights charter ought to be judged. Proposals for a national rights charter should clearly also be assessed by reference to a number of other criteria, including concerns about the impact of a national charter on the federal system, on the achievement of particular ideals of social justice and on the operation of various substantive areas of law.

On federalism grounds, in particular, there may be some argument to be made in favour of a Britishstyle charter over Canadian-style one, if a national charter is to apply to state as well as federal law. ${ }^{124}$

When it comes to a power of legislative amendment or suspension such as that conferred by a Canadian-style charter, state Parliaments will be far more constrained than the federal Parliament in their ability to make use of such mechanisms. They will clearly lack power to amend the terms of a federal rights charter, as interpreted by the Court. They will also in many cases, by virtue of s 109 of the Constitution, have limited power to impliedly suspend the operation of a charter in a way which expresses interpretive disagreement with the Court.

120 See John Darnton, British Labor Party Sheds Marx for Middle Class, NEw YoRK TiMES, October 5 , 1994 (detailing future Prime Minister Tony Blair's law and order priorities at time of assuming leadership of British Labor); The Blair Story, BBC.COM, May 10, 2007 (on the broad priorities of the Blair government, and legislative majority, from 1997-2007). For cases in which such concerns might have been thought to be particularly relevant, see e.g. Offen (narrowing the range of cases in which an automatic life sentence would apply) Sim (narrowing the circumstances in which a prisoner recalled from release on licence could be held in custody, by "reading-down" the apparent presumption in favor of continued detention, so as to create a presumption in favor of release.)

121 Sauvé v. Canada (A.G.) [1993] 2 S.C.R. 438; Corbiere v. Canada (Minister of Indian and Northern Affairs), [1999] 2 S.C.R 203; Figueroa v. Canada (Attorney General) [2003] 1 S.C.R. 912.

122 R v. Vaillancourt, [1987] 2 S.C.R. 636; Ford v. Quebec (A.G) [1988] 2 S.C.R. 712; R v. Bain, [1991] 1 S.C.R. 91; Committee for the Commonwealth of Canada v. Canada, [1991] 1 S.C.R 139; R v. Swain, [1991] 1 S.C.R 933; R v. Seaboyer, [1991] 2 S.C.R 577; R v. Zundel, [1992] 2 S.C.R. 731; R v. Morales, [1992] 3 S.C.R 711; Sauvé v. Canada (A.G.) [1993] 2 S.C.R. 438; R v. Daviault [1994] 3 S.C.R. 761; RJR-MacDonald Inc. v. Canada (A.G.) [1995] 3 S.C.R. 199; Thomson Newspapers v. Canada (Attorney General), [1998] 1 S.C.R. 877.

123 The exception is Ford. See nx supra.

124 Cf Australian Bill of Rights Bill 1985 (Cth). 
Section 109 of the Constitution provides that '[w]hen a law of a State is inconsistent with a law of the Commonwealth, the latter shall prevail, and the former shall, to the extent of the inconsistency, be invalid.' The High Court has also held that 'inconsistency' may be direct or indirect. It may arise from a conflict of duties, or rights and duties, created by federal as opposed to state law ('direct inconsistency'), or from the conflict which arises between state and federal law where state law continues to apply in circumstances where Parliament has intended to 'cover the field' in a particular area ('indirect inconsistency'). ${ }^{25}$ Direct inconsistency, in turn, will be measured by the Court without any reference to the intention of Parliament as to whether such a conflict should exist. ${ }^{126}$ Even if the federal Parliament were to pass a law in support of a state Parliament's attempt to engage in dialogue, by providing, for example, that a charter 'was not intended to apply to, or interfere with, the operation of' a particular state law, state Parliaments would have limited ability to use implied repeal as a tool for disagreeing with the Court about its preferred interpretation of charter rights.

By contrast, a power of non-implementation such as that created by issuing a declaration of incompatibility could just as readily be exercised by state Parliaments, as by the federal Parliament. Adoption of a British-style charter could help ensure that, if a national rights charter were to bind the states, it would do so in a way which was as minimalist as possible from the standpoint of federalism ${ }^{127}$.

Existing debates about a national rights charter tend, however, to focus almost exclusively on the issue of the horizontal balance between the High Court and federal Parliament rather than on vertical balance between the Court and state Parliaments; and in this context, this paper has sought to show that the current orthodoxy in favor of a British-style charter is dangerously misguided.

Rather than encouraging greater dialogue, a UK-style declaration of incompatibility mechanism has done exactly the opposite. In civil and criminal cases, in particular, it has encouraged statutory distortion of a kind which has seriously undermined the willingness of Westminster to engage in dialogue with the English courts under the UK HRA. In Australia, one should also expect that this distortion - and damage to dialogue - will be even greater, given our distinct constitutional framework.

Readers with comments may address them to:

Professor Rosalind Dixon

University of Chicago Law School

1111 East 60th Street

Chicago, IL 60637

dixon@uchicago.edu

125 See, eg, Clyde Engineering Co Ltd v Cowburn (1926) 37 CLR 466, 478 (Knox CJ and Gavan Duffy J) (holding that direct inconsistency can arise where a Commonwealth law grants a right the exercise of which a state law interferes with); University of Wollongong v Metwally (1984) 158 CLR 447 ('Metwally') (outlining nature of tests for direct and indirect inconsistency).

126 See Metwally (1984) 158 CLR 447 (holding that Parliament cannot unilaterally define, retrospectively, the scope of even indirect inconsistency).

127 It is worth noting that a Canadian-style charter could potentially achieve the same result by providing for a power of state parliamentary override similar to that found in s 33 of the Canadian Charter of Rights and Freedoms 1982. For such a power to be effective in all cases, however, s 109 of the Constitution would need to be amended, via the referendum process in s 128 of the Constitution, so as to give constitutional precedence to such an override power. While such a process need not lead to a constitutionally entrenched, and therefore maximalist, rights charter at the level of substance (it could, eg, simply involve an attempt to give Parliament power to enact a statutory rights charter that modifies the effect of s 109), from a procedural perspective, it would clearly mean that the enactment of a statutory charter was far from minimalist. 


\section{The University of Chicago Law School Public Law and Legal Theory Working Paper Series}

For a listing of papers 1-250 please go to http://www.law.uchicago.edu/academics/publiclaw/1-199.html

251. Tom Ginsburg, The Clash of Commitments at the International Criminal Court (November 2008)

252. Tom Ginsburg, Constitutional Afterlife: The Continuing Impact of Thailand's Post-Political Constitution (November 2008)

253. Cass R. Sunstein and Richard Zechkauser, Overreaction to Fearsome Risks (December 2008)

254. Gilbert Metcalf and David Weisbach, The Design of a Carbon Tax (January 2009)

255. David Weisbach, Responsibility for Climate Change, by the Numbers (January 2009)

256. Daniel Abebe, Great Power Politics and the Structure of Foreign Relations Law (January 2009)

257. Brian Leiter, Moral Skepticizm and Moral Disagreement in Nietzsche (January 2009)

258. Adam B. Cox, Immigration Law’s Organizing Principles, (February 2009)

259. Adam Samaha, Gun Control after Heller: Threats and Sideshows from a Social Welfare Perspective (February 2009)

260. Lior Strahilevitz, The Right to Abandon (February 2009)

261. Lee Fennell, Commons, Anticommons, Semicommons (February 2009)

262. Adam B. Cox and Cristina M. Rodríguez, The President and Immigration Law (March 2009)

263. Mary Anne Case, A Few Words in Favor of Cultivating an Incest Taboo in the Workplace (April 2009)

264. Adam B. Cox and Eric A. Posner, The Rights of Migrants (April 2009)

265. John Bronsteen, Christopher J. Buccafucso, and Jonathan S. Masur, Welfare as Happiness (June 2009)

266. Mary Anne Case, No Male or Female, but All Are One (June 2009)

267. Bernard E. Harcourt, Alon Harel, Ken Levy, Michael M. O’Hear, and Alice Ristroph, Randomization in Criminal Justice: A Criminal Law Conversation (June 2009)

268. Bernard E. Harcourt, Neoliberal Penality: A Brief Genealogy (June 2009)

269. Lee Anne Fennell, Willpower and Legal Policy (June 2009)

270. Brian Leiter, Nietzsche’s Philosophy of Action, July 2009

271. David A. Strauss, The Modernizing Mission of Judicial Review, July 2009

272. Lee Anne Fennell and Julie Roin, Controlling Residential Stakes, July 2009

273. Adam M. Samaha, Randomization in Adjudication, July 2009

274. Jonathan Masur and Eric A. Posner, Against Feasibility Analysis, August 2009

275. Brian Leiter, Foundations of Religious Liberty: Toleration or Respect?, October 2009

276. Eric A. Posner and Adrian Vermeule, Tyrannophobia, September 2009

277. Bernard E. Harcourt, Henry Louis Gates and Racial Profiling: What's the Problem? September 2009

278. Lee Anne Fennell, The Unbounded Home, Property Values beyond Property Lines, August 2009

279. Brian Leiter, The Epistemic Status of the Human Sciences: Critical Reflections on Foucault, October 2009

280. Ward Farnsworth, Dustin F. Guzior, and Anup Malani, Ambiguity about Ambiguity: An Empirical Inquiry into Legal Interpretation, October 2009

281. Anup Malani, Oliver Bemborn and Mark van der Laan, Accounting for Differences among Patients in the FDA Approval Process, October 2009

282. Saul Levmore, Ambiguous Statutes, November 2009

283. Rosalind Dixon, Female Justices, Feminism and the Politics of Judicial Appointment: A Reexamination, November 2009

284. Rosalind Dixon, The Supreme Court of Canada, Charter Dialogue and Deference, November 2009 
285. Rosalind Dixon, A Minimalist Charter of Rights for Australia: The U.K. or Canada as a Model? November 2009 